\title{
Analisis Logam Timbal (Pb) pada Lipstik yang Beredar di Kecamatan Pasar Jambi
}

\author{
Sholeha Annisa Martines ${ }^{1}$, Madyawati Latief ${ }^{2}$, Havizur Rahman ${ }^{1}$ \\ ${ }^{1}$ Program Studi Farmasi, Fakultas Sains dan Teknologi, Universitas Jambi, Jambi \\ ${ }^{2}$ Program Studi Kimia, Fakultas Sains dan Teknologi, Universitas Jambi, Jambi
}

*Corresponding author: sholehaannisam@gmail.com

\begin{abstract}
Background: Lipstick is a cosmetic product made by cast printing from solid-based materials containing dissolved and/or suspended dyes that meet the requirement criteria as a dye. This preparations contain waxes, oils, and dyes as the three main ingredients and some additional material as antioxidants, preservatives, and fragrances. Lead $(\mathrm{Pb})$ in cosmetic products can come from some naturally occurring substances containing lead $(P b)$ (such as dyes and pigments) or equipment used during the production process. Objective: The purpose of the research is to find out the metal levels of lead $(\mathrm{Pb})$ contained in preparations lipstick that is circulating in the market of Jambi. Methods: The method used to find out the levels of lead $(\mathrm{Pb})$ are qualitatively using color reagents and quantitatively using AAS (Atomic Absorption Spectrophotometer). Results: The results obtained from the ten sample lipstick that was used positive contain lead $(\mathrm{Pb})$ heavy metals is characterized by the formation of a yellow precipitate by KI reagent. The average levels of the lead (Pb) heavy metal in lipstick is $0.899 \mu \mathrm{g} / \mathrm{g}$. Conclusion: It is informed that the lipstick that is circulating in the market of Jambi is safe if used by the community. On the basis of regulations issued by BPOM RI lead $(\mathrm{Pb})$ content limit of heavy metal in cosmetic $<20 \mu \mathrm{g} / \mathrm{g}$.
\end{abstract}

Keywords: lipstick, lead (Pb), atomic absorption spectrophotometer

\begin{abstract}
Abstrak
Pendahuluan: Lipstik adalah produk kosmetika yang dibuat dari cetak tuang bahan berbasis padatan yang mengandung bahan pewarna terlarut dan/atau tersuspensi yang memenuhi kriteria/persyaratan sebagai pewarna. Sediaan ini mengandung lilin, minyak, dan pewarna sebagai tiga bahan utama dan beberapa bahan tambahan sebagai antioksidan, pengawet, dan parfum. Timbal $(\mathrm{Pb})$ dalam produk kosmetik bisa berasal dari beberapa bahan alami yang mengandung timbal $(\mathrm{Pb})$ (seperti pewarna dan pigmen) atau peralatan yang digunakan selama proses produksi. Tujuan: Tujuan penelitian ini yaitu mengetahui kadar logam timbal $(\mathrm{Pb})$ yang terkandung dalam sediaan lipstik yang beredar di Kecamatan Pasar Jambi. Metode: Metode yang digunakan untuk mengetahui kadar timbal $(\mathrm{Pb})$ yaitu secara kualitatif menggunakan pereaksi warna dan secara kuantitatif menggunakan SSA (Spektrofotometer Serapan Atom). Hasil: Hasil yang diperoleh yaitu dari 10 sampel lipstik yang digunakan positif mengandung logam berat timbal $(\mathrm{Pb})$ ditandai dengan terbentuknya endapan kuning oleh reagen KI. Rata-rata kadar logam berat timbal $(\mathrm{Pb})$ pada lipstik adalah $0,899 \mu \mathrm{g} / \mathrm{g}$. Kesimpulan: Hal ini menginformasikan bahwa lipstik yang beredar di Kecamatan Pasar Jambi aman jika digunakan oleh masyarakat. Berdasarkan peraturan yang dikeluarkan oleh BPOM RI batas kandungan logam berat timbal $(\mathrm{Pb})$ dalam kosmetik yaitu $<20 \mu \mathrm{g} / \mathrm{g}$.
\end{abstract}

Kata Kunci: lipstik, timbal (Pb), spektrofotometer serapan atom

\section{PENDAHULUAN}

Kosmetik adalah zat yang digunakan sebagai produk perawatan pribadi untuk meningkatkan atau melindungi penampilan atau menutupi bau tubuh manusia (Massadeh dkk., 2017). Lipstik adalah produk kosmetika yang dibuat dari cetak tuang bahan berbasis padatan yang mengandung bahan pewarna terlarut dan/atau tersuspensi yang memenuhi kriteria atau persyaratan sebagai pewarna (Agoes, 2015). Sediaan ini mengandung lilin, minyak, dan pewarna sebagai tiga bahan utama dan beberapa bahan tambahan sebagai antioksidan, pengawet, dan parfum (Gao dkk., 
2014). Terdapat berbagai jenis produk lipstik yang dijual di pasaran dengan izin edar yang dikeluarkan oleh BPOM. Namun ada pula yang tidak terdaftar sehingga tidak memiliki izin edar secara resmi.

Di sisi lain, telah terjadi kekhawatiran konsumen bahwa kosmetik mengandung logam berat. Fokusnya adalah logam berat dengan sifat toksik yang signifikan seperti timbal $(\mathrm{Pb})$, arsenik $(\mathrm{As})$, kadmium $(\mathrm{Cd})$, dan merkuri (Hg) (Massadeh dkk., 2017). Timbal (Pb) dalam produk kosmetik bisa berasal dari beberapa bahan alami yang mengandung timbal $(\mathrm{Pb})$ (seperti pewarna dan pigmen) atau peralatan yang digunakan selama proses produksi (Sharafi dkk., 2015).

Jika timbal $(\mathrm{Pb})$ terakumulasi dalam tubuh, tingkat paparan dan konsekuensinya yang signifikan, maka timbal $(\mathrm{Pb})$ dapat membahayakan kesehatan yang serius, seperti keracunan akut dan kronis, serta perubahan patologis organ. Hal ini dapat menyebabkan penyakit pada sistem kardiovaskular, ginjal, tulang, dan hati, bahkan dapat menyebabkan kanker saat timbal $(\mathrm{Pb})$ berlebihan terakumulasi dalam tubuh manusia (Soares \& Nascentes, 2013). Timbal $(\mathrm{Pb})$ dalam tubuh terakumulasi dalam tulang, karena timbal $(\mathrm{Pb})$ dalam bentuk $\mathrm{Pb}^{2+}$ (ion timbal) dapat menggantikan keberadaan $\mathrm{Ca}^{2+}$ (ion kalsium) dalam jaringan tulang serta toksisitas timbal $(\mathrm{Pb})$ digolongkan berdasarkan organ yang dipengaruhinya (Arifiyana, 2018).

Berdasarkan penelitian Nourmoradi dkk. (2013), di Iran produk kosmetik lipstik yang sering digunakan memiliki kadar timbal $(\mathrm{Pb}) 0,08-5,20 \mu \mathrm{g} / \mathrm{g}$ dan kadmium (Cd) 4,08 - 60,20 $\mu \mathrm{g} / \mathrm{g}$. Menurut Yatimah (2014), di Ciputat sampel lipstik warna dark brown kode TR1 dan TR3 mengandung timbal $(\mathrm{Pb}) 29,75 \pm$ $2,98 \mu \mathrm{g} / \mathrm{g}$ dan $128,34 \pm 9,48 \mu \mathrm{g} / \mathrm{g}$. Selain itu warna shocking pink kode TR3 mengandung timbal $(\mathrm{Pb})$ $55,34 \pm 7,12 \mu \mathrm{g} / \mathrm{g}$.

Berdasarkan Mohamed dkk (2014), di Sudan evaluasi kandungan timbal $(\mathrm{Pb})$ dalam lipstik yang beredar menunjukkan konsentrasi timbal $(\mathrm{Pb})$ dalam lipstik berada pada berkisar $0,03-3,62 \mu \mathrm{g} / \mathrm{g}$ dengan timbal $(\mathrm{Pb})$ terdeteksi pada 83,30\% sampel yang diuji. Kandungan timbal $(\mathrm{Pb})$ yang terdeteksi pada semua sampel berada di bawah batas yang diizinkan oleh FDA (USA Food and Drug Administration) untuk timbal $(\mathrm{Pb}) 20 \mu \mathrm{g} / \mathrm{g}$.

Berbagai teknik analisis telah digunakan untuk penentuan logam dalam kosmetik, salah satunya yaitu FAAS (Flame Atomic Absorption Spectrometry). Sampel kompleks seperti lipstik memerlukan konversi ke bentuk yang kompatibel dengan instrumentasi untuk kalibrasi yang sederhana dan efektif (Soares \& Nascentes, 2013).

Di Jambi telah banyak beredar lipstik yang memiliki nomor registrasi dari BPOM. Uji pendahuluan yang telah dilakukan oleh peneliti terhadap sampel lipstik didapatkan hasil bahwa sampel tersebut mengandung kation timbal $\left(\mathrm{Pb}^{2+}\right)$. Komposisi lipstik tersebut mengandung beberapa bahan yang secara alami mengandung logam berat timbal $(\mathrm{Pb})$, yaitu: beeswax $(\leq 10 \mathrm{ppm})$, iron oxides $(\leq 10 \mathrm{ppm})$, dan titanium dioxide ( $\leq 60 \mathrm{ppm}$ ) (Rowe dkk., 2009). Logam berat yang terkandung pada bahan tersebut bisa berasal dari cemaran dalam proses pembuatannya. Berdasarkan ulasan tersebut, maka perlu dilaksanakan pengujian mengenai kadar logam timbal $(\mathrm{Pb})$ yang terkandung dalam sediaan lipstik yang beredar di Kecamatan Pasar Jambi.

\section{BAHAN DAN METODE}

Penelitian ini dilakukan pada bulan Maret - Juni 2018 di Laboratorium BLHD Kota Jambi serta Laboratorium Agroindustri dan Tanaman Obat, Fakultas Sains dan Teknologi, Universitas Jambi.

\section{Bahan}

Bahan yang digunakan yaitu $\mathrm{HNO}_{3} 65 \%$ p.a EMerck, $\mathrm{H}_{2} \mathrm{O}_{2} 30 \%$ p.a E-Merck, $\mathrm{Pb}\left(\mathrm{NO}_{3}\right)_{2}$ E-Merck, $\mathrm{KI}, \mathrm{NaOH}, \mathrm{HCl}$, aquabidest, aquadest, lipstik.

\section{Alat}

Alat yang dibutuhkan adalah SSA (Spektrofotometer Serapan Atom) Shimadzu tipe AA7000 , lemari asam, timbangan analitis, hot plate, pipet mikro, kertas saring Whatman No. 42, serta alat-alat gelas laboratorium.

\section{Metode}

\section{Pengambilan sampel}

Sampel yang digunakan yaitu satu merek lipstik yang teregistrasi oleh BPOM yang beredar di Kecamatan Pasar Jambi. Sampel diperoleh dari 5 toko, setiap toko diambil 2 sampel, jadi total sampel yang dianalisis yaitu 10 sampel merek sama dengan nomor batch berbeda. Teknik sampling yang digunakan yaitu purposive sampling. Berdasarkan Sabri \& Hastono (2010), pemilihan sampel dilakukan oleh orang yang mengenal populasi yang akan diteliti. Sehingga sampel tersebut representatif terhadap populasi yang diteliti. Karakteristik sampel lipstik yang dikehendaki yaitu lipstik yang beredar di Kecamatan Pasar Jambi. Sampel tersebut telah teregistrasi oleh BPOM. Harganya berkisar antara Rp 10.000 - Rp 12.000 serta memiliki seri warna yang diminati oleh masyarakat (orange pink). Lipstik tersebut kemasannya memiliki nomor 
batch, komposisi (Tabel 1), expired date dan nama produsen. Komposisinya yaitu sebagai berikut.

Tabel 1. Komposisi lipstik

\begin{tabular}{|c|c|}
\hline No. & Komposisi \\
\hline 1. & Castor (Ricinus communis) oil \\
\hline 2. & Myristil lactate \\
\hline 3. & Isopropyl myristate \\
\hline 4. & Isopropyl lanolate \\
\hline 5. & Candelilla (Euphorbia cerifera) wax \\
\hline 6. & Lanolin \\
\hline 7. & Petrolatum \\
\hline 8. & Beeswax \\
\hline 9. & Carnauba (Copernicia cerifera) wax \\
\hline 10. & Ozokerite \\
\hline 11. & Sorbitan sesquioleate \\
\hline 12. & Methylparaben \\
\hline 13. & Propylparaben \\
\hline 14. & Parfum \\
\hline 15. & $\mathrm{Cl} 15850$ \\
\hline 16. & $\mathrm{Cl} 45380$ \\
\hline 17. & $\mathrm{Cl} 45410$ \\
\hline 18. & $\mathrm{Cl} 45370$ \\
\hline 19. & $\mathrm{Cl} 42090$ \\
\hline 20. & Cl 19140 \\
\hline 21. & Cl 12085 \\
\hline 22. & $\mathrm{Cl} 77491$ \\
\hline 23. & $\mathrm{Cl} 77492$ \\
\hline 24. & Cl 77499 \\
\hline 25. & Cl 77742 \\
\hline 26. & $\mathrm{Cl} 77891$ \\
\hline 27. & $\mathrm{Cl} 42090$ \\
\hline 28. & $\mathrm{Cl} 77007$ \\
\hline 29. & $\mathrm{Cl} 77947$ \\
\hline 30. & $\mathrm{Cl} 75470$ \\
\hline 31. & $\mathrm{Cl} 77510$ \\
\hline
\end{tabular}

\section{Preparasi sampel}

Destruksi basah digunakan untuk preparasi sampel lipstik. Ditimbang masing-masing satu gram sampel dimasukkan ke beaker glass Pyrex $100 \mathrm{~mL}$ (Nourmoradi dkk., 2013). Ditambahkan $20 \mathrm{~mL} \mathrm{HNO}_{3}$ $65 \%$. Dipanaskan menggunakan hot plate dengan suhu $100^{\circ} \mathrm{C}$. Proses dilakukan hingga hilangnya asap berwarna coklat. Selanjutnya ditambahkan $1 \mathrm{~mL} \mathrm{H}_{2} \mathrm{O}_{2}$ pekat untuk mempercepat proses oksidasi. Larutan didinginkan terlebih dahulu. Lalu ditambahkan aquabidest hingga $50 \mathrm{~mL}$. Penyaringan dilakukan dengan kertas saring Whatman No. 42.

\section{Uji kualitatif kation timbal $\left(\mathrm{Pb}^{2+}\right)$}

Digunakan tiga pereaksi warna yaitu larutan KI, $\mathrm{NaOH}$, dan $\mathrm{HCl}$. Ditambahkan $2-3$ tetes larutan pereaksi dalam $1 \mathrm{~mL}$ larutan sampel. Terbentuknya endapan kuning (KI), putih $(\mathrm{NaOH})$, dan putih $(\mathrm{HCl})$ menunjukkan adanya kation timbal $\left(\mathrm{Pb}^{2+}\right)$ (Ayuni \& Yuningrat, 2014).

\section{Pembuatan larutan induk}

Dilarutkan $0,1598 \mathrm{~g} \mathrm{~Pb}\left(\mathrm{NO}_{3}\right)_{2}$ di dalam sejumlah kecil $\mathrm{HNO}_{3} 1+1\left(1 \mathrm{~mL} \mathrm{HNO}_{3}: 1 \mathrm{~mL}\right.$ aquadest $)$, ditambahkan $10 \mathrm{~mL} \mathrm{HNO}_{3}$ pekat. Diencerkan dengan aquadest sampai $1000 \mathrm{~mL}$. Dalam 1,00 mL larutan induk mengandung $100 \mu \mathrm{g}$ timbal (Pb) (APHA, 2012). Pembuatan kurva kalibrasi

Sebanyak $10 \mathrm{~mL}$ larutan induk timbal $(\mathrm{Pb})$ 1000 ppm lalu dituang ke labu ukur $100 \mathrm{~mL}$ menggunakan pipet. Diencerkan dengan aquabidest sampai dengan garis batas lalu ditambahkan $\mathrm{HNO}_{3}$ $1 \mathrm{~mL}$, pengenceran dilanjutkan hingga $100 \mathrm{~mL}$. Dikocok homogen dan diperoleh larutan konsentrasi $100 \mathrm{ppm}$. Selanjutnya larutan konsentrasi $100 \mathrm{ppm}$ diencerkan menjadi $2 \mathrm{ppm}$; 1,5 ppm; $1 \mathrm{ppm}$; 0,5 ppm; $0,2 \mathrm{ppm}$; dan $0 \mathrm{ppm}$. Kemudian diukur serapannya menggunakan spektrofotometer serapan atom pada panjang gelombang 283,3 nm (APHA, 2012).

\section{Validasi metode analisis}

\section{Uji linearitas}

Analisis regresi $y=a+b x$ digunakan untuk menghitung koefisien korelasi (r) (Harmita, 2004).

Keterangan:

$y=$ intensitas yang terbaca

$a=$ tetapan regresi (intersep)

$b=$ koefisien regresi (slope)

$x=$ konsentrasi

Uji batas deteksi (LOD) dan batas kuantitasi (LOQ)

Perhitungan LOD dan LOQ menggunakan persamaan regresi linear dari kurva kalibrasi (Harmita, 2004)

$\begin{aligned} \mathrm{LOD} & =\frac{3 S y / x}{S l} \\ \mathrm{LOQ} & =\frac{10 S y / x}{S l} \\ S y / x & =\sqrt{\frac{\sum(y-y i)^{2}}{n-2}}\end{aligned}$

Keterangan:

LOD = batas deteksi

LOQ = batas kuantitasi

$S y / x=$ simpangan baku residual

$\mathrm{Sl} \quad=$ slope

Pengujian menggunakan spektrofotometer serapan atom

Dibersihkan nebulizer spektrofotometer serapan atom dengan cara diaspirasikan aquadest yang mengandung $\quad 1,5 \quad \mathrm{~mL} \quad \mathrm{HNO}_{3}$ pekat/L aquadest. Kemudian diaspirasikan blanko ke dalam spektrofotometer serapan atom. Selanjutnya diaspirasikan sampel yang telah dipreparasi sebagai 
logam terlarut dan/atau logam total. Lalu dicatat absorbansinya (APHA, 2012).

\section{Penentuan kadar timbal $(\mathrm{Pb})$ di sampel}

Penentuan kadar timbal $(\mathrm{Pb})$ di sampel yaitu menggunakan persamaan regresi linier.

$y=b x+a$

Keterangan :

$x=$ absorbansi sampel

$y=$ konsentrasi sampel

$b=$ slope

$a=$ intersep

Berdasarkan BPOM RI (2014), perhitungan kadar logam berat timbal $(\mathrm{Pb})$ yaitu:

Logam $\mathrm{Pb}(\mu \mathrm{g} / \mathrm{g})=\frac{\mathrm{C}(\mu \mathrm{g} / \mathrm{ml})}{\mathrm{B}(\mathrm{g})} \mathrm{x} F(\mathrm{~mL})$

Keterangan :

$\mathrm{C}=$ konsentrasi timbal $(\mathrm{Pb})$ dalam sampel dari kurva kalibrasi

$\mathrm{F}=$ faktor pengenceran sampel

$\mathrm{B}=$ bobot sampel dari larutan uji

\section{Analisis data}

Pengujian secara kualitatif dilakukan dengan menggunakan reaksi warna serta pengujian secara kuantitatif menggunakan persamaan regresi linear. Penyajian data dilakukan dengan menggunakan tabel, diagram dan kurva kalibrasi.

\section{HASIL DAN PEMBAHASAN \\ Preparasi sampel}

Analisa suatu unsur logam pada sampel dengan spektrofotometer serapan atom, digunakan sampel dalam bentuk larutan. Metode destruksi basah umumnya digunakan untuk analisis logam-logam berat beracun yang tidak tahan pemanasan tinggi atau mudah menguap (Connors, 1982). Menurut Rasyid dkk. (2013), penentuan unsur dengan konsentrasi yang sangat rendah dapat menggunakan metode destruksi basah. Proses destruksi diharapkan dapat meninggalkan logamnya, sehingga dalam analisis unsurnya tidak saling mengganggu.
Pada penelitian ini digunakan $\mathrm{HNO}_{3} 65 \%$ yang berfungsi sebagai oksidator kuat, serta $\mathrm{H}_{2} \mathrm{O}_{2}$ sebagai katalis untuk menyempurnakan proses oksidasi. Pemanasan sampel dengan suhu $100^{\circ} \mathrm{C}$ bertujuan untuk mempercepat proses putusnya ikatan logam dengan senyawa organik. Selama proses tersebut menimbulkan asap coklat yang mengindikasikan zat organik dalam sampel telah teroksidasi. Hal ini sesuai dengan Wulandari \& Sukesi (2013) dalam Yatimah (2014), yaitu timbulnya asap kecoklatan artinya $\mathrm{HNO}_{3}$ telah mengoksidasi senyawa organik. Hal ini akan terus berulang selama proses destruksi, kemudian akan berakhir setelah semua bahan organik terdekomposisi semua.

\section{Uji kualitatif kation timbal $\left(\mathbf{P b}^{2^{+}}\right)$}

Pemisahan dan pengujian ion di dalam larutan yang mengacu pada prosedur laboratorium merupakan analisis kualitatif. Identifikasi kualitatif adanya kandungan logam berat dalam kosmetik dapat dilakukan dengan menambahkan reagen tertentu pada sampel kosmetik. Melalui penambahan ini sampel yang telah dipreparasi akan memberikan hasil berupa perubahan warna larutan atau reaksi yang menghasilkan endapan dengan warna tertentu (Arifiyana, 2018).

Pada penelitian ini digunakan pereaksi warna KI, $\mathrm{HCl}$, dan $\mathrm{NaOH}$. Hasil yang diperoleh ada di Tabel 2.

\section{Validasi metode analisis}

\section{Uji linearitas}

Linearitas merupakan kemampuan metode memperoleh hasil-hasil uji yang proporsional dengan konsentrasi analit pada kisaran yang diberikan. Selain itu, merupakan ukuran seberapa baik kurva kalibrasi yang menghubungkan respons (y) dengan konsentrasi (x) (Gandjar \& Rohman, 2017). Berdasarkan hasil yang diperoleh (Gambar 1) nilai koefisien korelasi (r) yaitu 0,99678 dimana nilai tersebut mendekati 1 . Hal ini menunjukkan bahwa konsentrasi sampel yang diperoleh dapat dihitung dari nilai absorbansi.

Tabel 2. Uji ualitatif kation timbal $\left(\mathrm{Pb}^{2+}\right)$

\begin{tabular}{ccccc}
\hline \multirow{2}{*}{ No. } & Nama Sampel & \multicolumn{3}{c}{ kKeterangan } \\
\cline { 3 - 5 } & & KI & HCl & NaOH \\
\hline 1. & $1 \mathrm{~A}$ & + & - & - \\
2. & $1 \mathrm{~B}$ & + & - & - \\
3. & $2 \mathrm{~A}$ & + & - & - \\
4. & $2 \mathrm{~B}$ & + & - & - \\
5. & $3 \mathrm{~A}$ & + & - & - \\
6. & $3 \mathrm{~B}$ & + & - & - \\
7. & $4 \mathrm{~A}$ & + & - & - \\
8. & $4 \mathrm{~B}$ & + & - & - \\
9. & $5 \mathrm{~A}$ & + & - & - \\
10. & $5 \mathrm{~B}$ & + & - & - \\
\hline
\end{tabular}




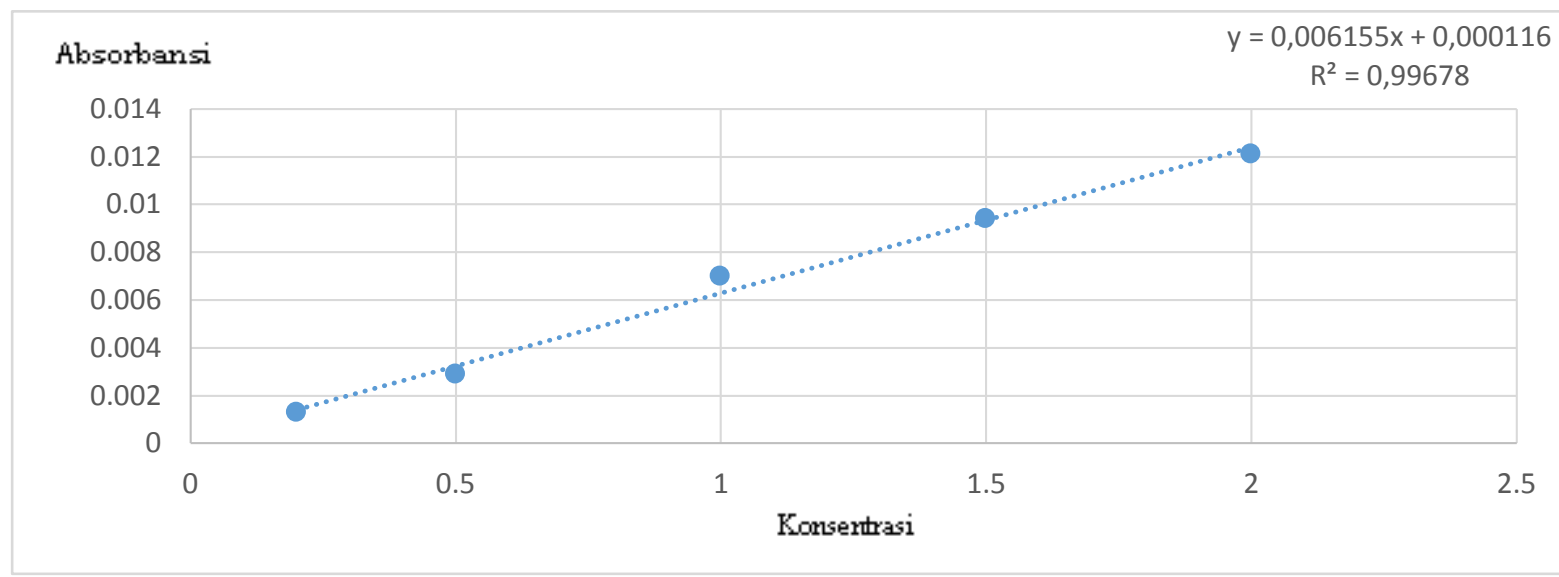

Gambar 1. Kurva kalibrasi timbal $(\mathrm{Pb})$

\section{Uji batas deteksi (LOD) dan batas kuantitasi (LOQ)}

Jumlah terkecil analit dalam sampel yang dapat dideteksi yang masih memberikan respon signifikan dibandingkan dengan blanko yang disebut sebagai batas deteksi (LOD). Sedangkan parameter pada analisis renik dan diartikan sebagai kuantitas terkecil analit dalam sampel yang masih dapat memenuhi kriteria cermat dan seksama disebut sebagai batas kuantitasi (LOQ). Ada beberapa cara untuk memperoleh nilai LOD dan LOQ yaitu signal to noise, penentuan blanko, dan kurva kalibrasi (Rohman, 2018).

Nilai LOD dan LOQ yang diperoleh dari logam timbal $(\mathrm{Pb})$ diperoleh dari perhitungan statistika menggunakan metode kurva kalibrasi. Hasilnya yaitu nilai LOD 0,195 ppm dan LOQ 0,649 ppm. Hal ini menginformasikan bahwa metode tersebut dapat digunakan untuk analisis logam timbal $(\mathrm{Pb})$. Terpenuhinya syarat uji sensitivitas karena memberikan respon yang signifikan dalam tiap pengukuran, serta memberikan hasil yang termasuk cermat dan seksama (Dewi, 2011).

\section{Penentuan kadar timbal (Pb) di sampel}

Spektrofotometer serapan atom digunakan untuk menentukan kadar timbal $(\mathrm{Pb})$ di sampel. Pengukuran hasil destruksi sampel pada panjang gelombang 283,3 nm karena terjadi penyerapan cahaya oleh atom untuk melakukan transisi elektron dari tingkat dasar ke tingkat eksitasi (Dewi, 2012). Menurut Yuyun dkk (2017), penggunaan metode spektrofotometri serapan atom dikarenakan memiliki sensitifitas yang tinggi, proses cepat, jumlah cuplikan sedikit, spesifik terhadap unsur yang dianalisis, serta dapat digunakan untuk penentuan kadar unsur yang sangat rendah.

Hasil analisis kuantitatif (Tabel 3) menggunakan spektrofotometer serapan atom menunjukkan bahwa logam timbal $(\mathrm{Pb})$ terdeteksi dalam semua sampel lipstik yang diuji.

Tabel 3. Kadar timbal $(\mathrm{Pb})$ dalam lipstik

\begin{tabular}{ccccc}
\hline No. & Kode Sampel & Rata-Rata Absorban & Rata-Rata Konsentrasi $(\mu \mathrm{g} / \mathrm{mL})$ & Rata-Rata Kadar Timbal $(\mu \mathrm{g} / \mathrm{g})$ \\
\hline 1. & $1 \mathrm{~A}$ & $2 \times 10^{-4}$ & $14 \times 10^{-2} \pm 0,00$ & $64 \times 10^{-1} \pm 84 \times 10^{-6}$ \\
2. & $1 \mathrm{~B}$ & $2 \times 10^{-4}$ & $14 \times 10^{-2} \pm 0,00$ & $64 \times 10^{-1} \pm 84 \times 10^{-6}$ \\
3. & $2 \mathrm{~A}$ & $2 \times 10^{-4}$ & $22 \times 10^{-2} \pm 11 \times 10^{-2}$ & $1,00 \pm 51 \times 10^{-1}$ \\
4. & $2 \mathrm{~B}$ & $3 \times 10^{-4}$ & $3 \times 10^{-2} \pm 0,00$ & $1,37 \pm 18 \times 10^{-4}$ \\
5. & $3 \mathrm{~A}$ & $25 \times 10^{-4}$ & $22 \times 10^{-2} \pm 11 \times 10^{-2}$ & $1,00 \pm 51 \times 10^{-1}$ \\
6. & $3 \mathrm{~B}$ & $25 \times 10^{-4}$ & $22 \times 10^{-2} \pm 11 \times 10^{-2}$ & $1,00 \pm 51 \times 10^{-1}$ \\
7. & 4 A & $25 \times 10^{-4}$ & $22 \times 10^{-2} \pm 11 \times 10^{-2}$ & $1,00 \pm 51 \times 10^{-1}$ \\
8. & 4 B & $2 \times 10^{-4}$ & $14 \times 10^{-2} \pm 0,00$ & $64 \times 10^{-1} \pm 84 \times 10^{-6}$ \\
9. & 5 A & $25 \times 10^{-4}$ & $22 \times 10^{-2} \pm 11 \times 10^{-2}$ & $1,00 \pm 51 \times 10^{-1}$ \\
10. & 5 B & $2 \times 10^{-4}$ & $14 \times 10^{-2} \pm 0,00$ & $64 \times 10^{-1} \pm 12 \times 10^{-4}$ \\
\hline
\end{tabular}

Semua sampel lipstik tersebut mengandung logam berat timbal $(\mathrm{Pb})$ dengan kadar (Gambar 2) yang rendah serta sesuai dengan Peraturan Kepala BPOM RI Nomor 17 Tahun 2014 yang menyatakan bahwa kandungan logam berat timbal $(\mathrm{Pb})$ pada kosmetik yaitu $<20 \mu \mathrm{g} / \mathrm{g}$. Secara menyeluruh, rata-rata kadar logam berat timbal $(\mathrm{Pb})$ dalam penelitian ini yaitu $0,899 \mu \mathrm{g} / \mathrm{g}$. Hal tersebut menginformasikan bahwa lipstik yang beredar di Pasar Jambi aman dan tidak berbahaya bagi kesehatan jika digunakan oleh masyarakat. 


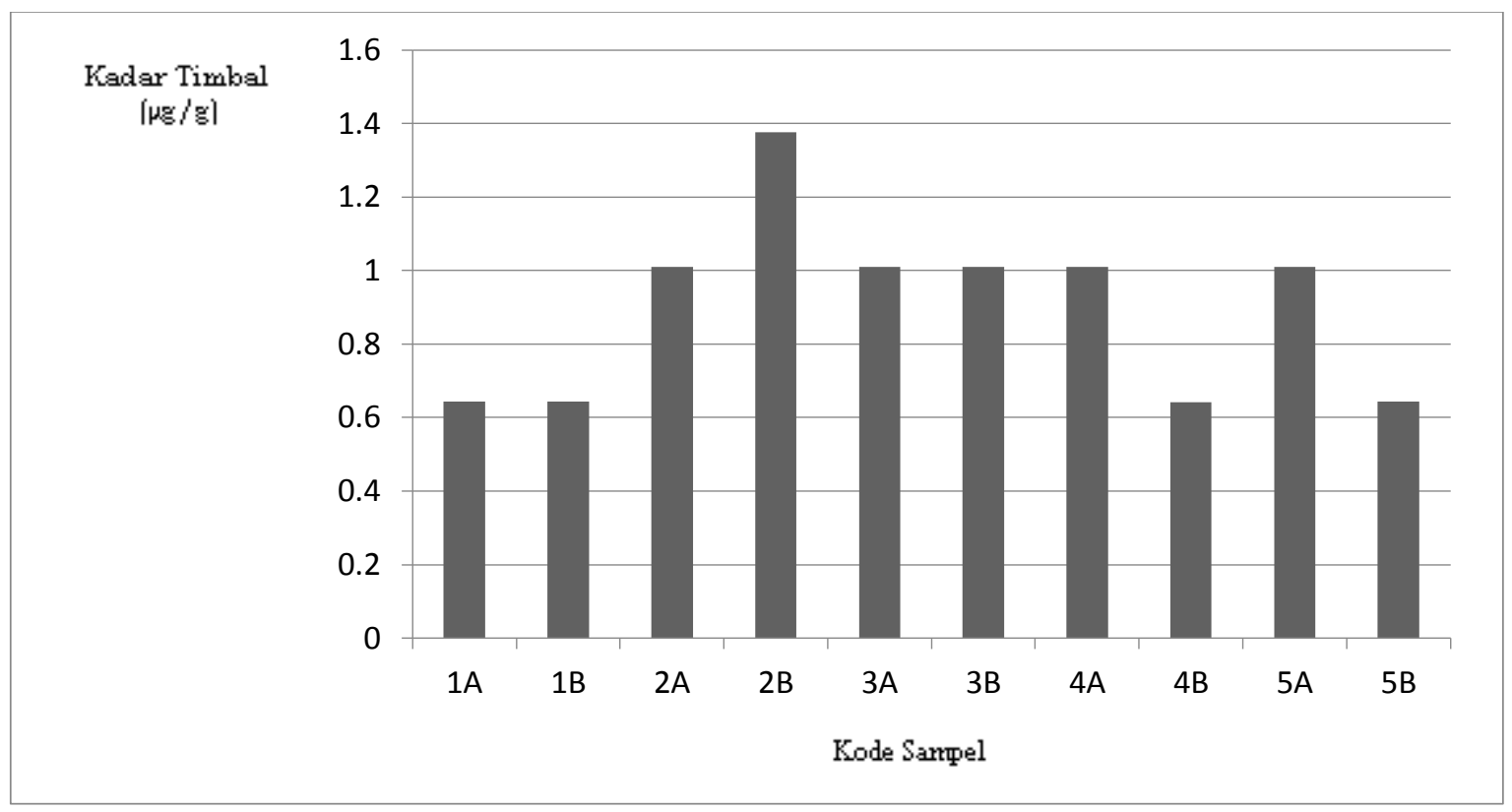

Gambar 2. Grafik kadar timbal $(\mathrm{Pb})$ lipstik

Perbedaan hasil yang diperoleh dengan yang telah dilaporkan oleh Nourmoradi dkk. (2013) kandungan timbal $(\mathrm{Pb})$ pada lipstik yang sering digunakan di Iran yaitu 0,08 - 5,20 $\mu \mathrm{g} / \mathrm{g}$. Selain itu Effendi dkk. (2014) menyatakan bahwa lipstik yang beredar di Makassar mengandung logam timbal $(\mathrm{Pb})$ sebesar 3,504 $56,649 \mu \mathrm{g} / \mathrm{g}$. Berdasarkan penelitian Elizabeth dkk. (2015) bahwa lipstik di Medan yang terdaftar dan tidak terdaftar di BPOM mengandung logam timbal $(\mathrm{Pb})$ dengan kadar 0,8146 - 5,5916 mg/Kg.

Nilai rata-rata konsentrasi dan kadar timbal $(\mathrm{Pb})$ yang diperoleh dari sampel lipstik (Tabel 3) memiliki nilai standar deviasi yang kecil. Akar dari varian merupakan standar deviasi atau disebut juga sebagai simpangan baku karena merupakan patokan luas area di bawah kurva normal. Sedangkan variasi data di dalam kelompok data terhadap nilai rata-rata termasuk nilai variasi atau deviasi. Jika semakin besar nilai variasi, maka semakin bervariasi pula data tersebut (Sabri \& Hastono, 2010).

\section{KESIMPULAN}

1. Sediaan lipstik yang beredar di Kecamatan Pasar Jambi positif mengandung logam timbal $(\mathrm{Pb})$ dengan kadar rata-rata $0,899 \mu \mathrm{g} / \mathrm{g}$.

2. Kadar logam timbal $(\mathrm{Pb})$ pada lipstik tidak melebihi batas $(<20 \mu \mathrm{g} / \mathrm{g})$ yang ditetapkan oleh BPOM RI.

\section{DAFTAR PUSTAKA}

Agoes, G. (2015). Sediaan Kosmetik (SFI-9). Bandung: ITB Press.
APHA. (2012). Standard Method for the Examination of Water and Wastewater (22nd Ed.). New York: American Public Health Association Inc.

Arifiyana, D. (2018). Identifikasi Cemaran Logam Berat Timbal $(\mathrm{Pb})$ pada Lipstik yang Beredar di Pasar Darmo Trade Center (DTC) Surabaya dengan Reagen Sederhana. Journal of Pharmacy and Science; 3; 13-16.

Ayuni, N. P. S. A. \& Yuningrat, N. W. (2014). Kimia Analitik: Analisis Kualitatif dan Pemisahan Kimia. Yogyakarta: Graha Ilmu.

BPOM RI. (2014). Peraturan Kepala Badan Pengawas Obat dan Makanan Republik Indonesia Nomor 17 Tahun 2014 tentang Perubahan atas Peraturan Kepala Badan Pengawas Obat dan Makanan Nomor HK.03.1.23.07.11.6662 Tahun 2011 tentang Persyaratan Cemaran Mikroba dan Logam Berat dalam Kosmetika. Jakarta: BPOM.

Connors, K. A. (1982). A Textbook of Pharmaceutical Analysis. New York: John Wiley \& Sons Inc.

Dewi. (2011). Analisa Cemaran Logam Timbal (Pb), Tembaga (Cu), dan Kadmium (Cd) dalam Tepung Gandum secara Spektrofotometri Serapan Atom. Skripsi; Fakultas Matematika dan Ilmu Pengetahuan Alam Universitas Indonesia, Jakarta.

Dewi, D. C. (2012). Determinasi Kadar Logam Timbal $(\mathrm{Pb})$ dalam Makanan Kaleng Menggunakan Destruksi Basah dan Destruksi Kering. Alchemy; 2; 12-25.

Effendi, N., Pratama, M. \& Kamaruddin, H. (2014). Analisis Kandungan Logam Berat Merkuri $(\mathrm{Hg})$ 
dan Timbal $(\mathrm{Pb})$ pada Kosmetik Lipstik yang Beredar di Kota Makassar dengan Metode Spektrofotometri Serapan Atom. As-Syifaa; 6; 82-90.

Elizabeth, P., Nurmaini \& I. Chahaya, S. (2015). Analisis Kandungan Logam Timbal $(\mathrm{Pb})$ pada Lipstik Lokal yang Teregistrasi dan Tidak Teregistrasi Badan Pengawas Obat dan Makanan (BPOM) serta Tingkat Pengetahuan dan Sikap Konsumen Terhadap Lipstik yang Dijual di Beberapa Pasar di Kota Medan Tahun 2015. Jurnal Lingkungan dan Keselamatan Kerja; 4; 1-10.

Gandjar, I. G. \& Rohman, A. (2017). Kimia Farmasi Analisis (Cetakan ke enam belas). Yogyakarta: Pustaka Pelajar.

Gao, P., Liu, S., Zhang, Z., Meng, P., Lin, N., Lu, B., Cui, F., Feng, Y. \& Xing, B. (2014). Health Impact of Bioaccessible Metal in Lip Cosmetics to Female College Students and Career Women, Northeast of China. Enviromental Pollution; 197; 214-220.

Harmita. (2004). Petunjuk Pelaksanaan Validasi Metode dan Cara Perhitungannya. Majalah Ilmu Kefarmasian; 1; 117-135.

Massadeh, A. M., El-khateeb, M. Y. \& Ibrahim, S. M. (2017). Evaluation of $\mathrm{Cd}, \mathrm{Cr}, \mathrm{Cu}, \mathrm{Ni}$, and $\mathrm{Pb}$ in selected Cosmetic Products from Jordanian, Sudanese, and Syrian markets. Public Health; 149; 130-137.

Mohamed, F. A. H., Osman, B., Kariem, E. A. G., Abdoon, I. H. \& Mohamed, M. A. (2014). Evaluation of Lead Content in Topical Cosmetics Commonly Used in Sudan. World Journal of Pharmaceutical Research; 4; 204211.

Nourmoradi, H., Foroghi, M., Farhadkhani, M. \& Dastjerdi, M. V. (2013). Assessment of Lead and Cadmium Levels in Frequently Used Cosmetic Products in Iran. Journal of Environmental and Public Health; 1-5.
Rasyid, R., Humairah \& Zulharmitta. (2013). Analisis Kadmium (Cd), Seng (Zn) dan Timbal $(\mathrm{Pb})$ pada Susu Kental Manis Kemasan Kaleng secara Spektrofotometri Serapan Atom (SSA). Jurnal Farmasi Higea; 5; 62-71.

Rohman, A. (2018). Validasi Penjaminan Mutu Metode Analisis Kimia. Yogyakarta: UGM Press.

Rowe, R. C., Sheskey, P. J. \& M. E. Quinn. (2009). Handbook of Pharmaceutical Excipients, Sixth Edition. USA: Pharmaceutical Press and American Pharmacists Association.

Sabri, L. \& Hastono, S. P. (2010). Statistik Kesehatan. Jakarta: PT. Raja Grafindo Persada.

Sharafi, K., Fattahi, N., Pirsaheb, M., Yarmoharmadi, H. \& Davil, M. F. (2015). Trace Determination of Lead in Lipsticks and Hair Dyes using Microwave-assisted Dispersive Liquid-liquid Microextraction and Graphite Furnace Atomic Absorption Spectrometry. International Journal of Cosmetic Science; 37; 489-495.

Soares, A. R. \& Nascentes, C. C. (2013). Development of a Simple Method for the Determination of Lead in Lipstick Using Alkaline Solubilization and Graphite Furnace Atomic Absorption Spectrometry. Talanta; 105; 272-277.

Wulandari, E. A. \& Sukesi. (2013). Preparasi Penentuan Kadar Logam $\mathrm{Pb}, \mathrm{Cd}$, dan $\mathrm{Cu}$ dalam Nugget Ayam Rumput Laut Merah (Eucheuma cottonii). Jurnal Sains dan Seni Pomits; 2; $15-$ 17.

Yatimah, Y. D. (2014). Analisa Cemaran Logam Berat Kadmium dan Timbal pada Beberapa Merek Lipstik yang Beredar di Daerah Ciputat dengan Menggunakan Spektrofotometri Serapan Atom (SSA). Skripsi; Fakultas Kedokteran dan Ilmu Kesehatan UIN Syarif Hidayatullah, Jakarta.

Yuyun, Y., Peuru, A. R. A. \& Ibrahim, N. (2017). Analisis Kandungan Logam Berat Timbal dan Kadmium pada Pengolahan Ikan Asin di Kabupaten Banggai Kepulauan. Journal of Pharmacy; 3; 71-76. 